\title{
Optimization of self-assembling properties of fatty acids grafted to methoxy poly(ethylene glycol) as nanocarriers for etoposide
}

\author{
JALEH VARSHOSAZ ${ }^{1 *}$ \\ FARSHID HASANZADEH ${ }^{2}$ \\ MOJTABA ESLAMDOOST ${ }^{1}$ \\ 1 Department of Pharmaceutics \\ Faculty of Pharmacy and Isfahan \\ Pharmaceutical Sciences Research Center \\ Isfahan University of Medical Sciences \\ Isfahan, Iran \\ ${ }^{2}$ Department of Medicinal Chemistry \\ Faculty of Pharmacy and Isfahan \\ Pharmaceutical Sciences Research Center \\ Isfahan University of Medical Sciences \\ Isfahan, Iran
}

\begin{abstract}
The objective of this work was to study the effect of fatty acid chain length grafted to methoxy poly(ethylene glycol) (mPEG) on self assembling properties of micelles for etoposide delivery. Three amphiphilic copolymers were synthesized using mPEG, myristic acid, stearic acid and behenic acid through an esteric linkage. The particle size and zeta potential of the micelles were determined by the dynamic light scattering method. Etoposide was loaded into micelles by film casting using various drug/polymer ratios. Drug release was studied by the dialysis method. The structure of copolymers was confirmed by ${ }^{1} \mathrm{H}$ NMR and FTIR. Central micellar concentration (CMC) measurements showed that the longer hydrophobic chains formed more thermodynamically stable micelles. Among the prepared copolymers, etoposide showed the highest solubility in the mPEG-behenic copolymer. Drug loading efficiency depended on the hydrophobic chain length and drug/polymer ratio. The highest drug loading efficiency was found in mPEG-myristic micelles with 1:20 drug/polymer ratio. Micelles released $80 \%$ of loaded drug within about $5 \mathrm{~h}$.
\end{abstract}

Keywords: methoxy poly(ethylene glycol), fatty acid, micelles, etoposide

Amphiphilic block copolymers tend to self-assemble in an aqueous phase and form micelles. These polymeric micelles have nanoscale, high thermodynamic and kinetic stability and can solubilize hydrophobic substances; therefore, they may be applied to separation systems, drug delivery systems, pharmaceuticals, or emulsion stabilization (1-3). Polymeric micelles composed of block copolymers show a core-shell micellar structure with a hydrophobic inner core surrounded by a hydrated outer shell in aqueous solution. Hydrophobic drugs can be incorporated into the hydrophobic inner core and the hydrated outer shell helps prevent opsonization of the carrier and uptake by the reticu-

\footnotetext{
* Correspondence; e-mail: varshosaz@pharm.mui.ac.ir
} 
loendothelial system. Polymeric micelles have the advantages of small particle size, good structural stability, easy production in large quantities and reproducibly, favorable biodistribution, easy sterilization and improved solubility and bioavailaibility of poorly water-soluble anticancer drugs $(4,5)$. Polymeric micelles can therefore increase the quantities of drug delivered to the cells with high efficacy and low side effects (6-8). Since water concentration in the micellar core is low, hydrolytic degradation may be reduced, resulting in increased chemical stability of the drug.

Etoposide is a lipophilic anticancer agent used in the treatment of various malignancies (9). It is a topoisomerase-II inhibitor that acts through activation of oxidation-reduction reactions to produce derivatives that bind directly to DNA and cause DNA damage $(9,10)$. Etoposide has a short biological half-life (3.6 hours), with terminal half-life of 1.5 hours by intravenous route and variable oral bioavailability ranging from 24-74 \%. Although intraperitoneal injection would result in initial high local tumor concentrations, prolonged exposure of tumor cells may not be possible (11). The tumoricidal effects of etoposide incorporated into lipid nanoparticles after a single-dose administration showed stronger and prolonged apoptotic induction properties, resulting in higher increase in the survival time of tumor bearing mice (11).

The aim of the present study was to improve water solubility of etoposide by preparing etoposide-loaded nanomicelles of $\mathrm{mPEG}$ and fatty acids.

\section{EXPERIMENTAL}

\section{Materials}

Myristoyl chloride, stearoyl chloride and behenoyl chloride were purchased from Aldrich Company (USA), mPEG (Fluka, USA), pyrene (Sigma, USA) and etoposide (Beijing Lunarsun Pharmaceutical Co., Ltd., China). $\mathrm{KBr}, \mathrm{NaOH}, \mathrm{KHPO}_{4}$ and all solvents such as toluene and triethylamine used in this study were of analytical grade and were purchased from Merck (Germany).

\section{Synthesis of mPEG-fatty acid conjugate}

For conjugation of mPEG to fatty acids [myristic acid (Ma) $\left(\mathrm{C}_{14}\right)$, stearic acid (Sa) $\left(\mathrm{C}_{18}\right)$ and behenic acid $\left.(\mathrm{Ba})\left(\mathrm{C}_{22}\right)\right]$, the acyl chloride form of fatty acids was used by the modified method reported by Sahu et al. (12). mPEG was mixed and dissolved in triethylamine (final concentration $\left.10 \mathrm{mmol} \mathrm{L}^{-1}\right)$. A solution of acyl chloride $\left(11 \mathrm{mmol} \mathrm{L}^{-1}\right)$ in toluene was added dropwise and stirred continuously for $3 \mathrm{~h}$ at $60{ }^{\circ} \mathrm{C}$. The solution was then filtered through filter paper (Whatman, UK) to remove the precipitated triethylamine hydrochloride salt. $\mathrm{NaOH}\left(0.5 \mathrm{~mol} \mathrm{~L}^{-1}\right)$ solution was then added to remove unreacted acyl chloride and mPEG. The toluene that remained in the solution was removed by vacuum distillation to produce a dry powder. 
J. Varshosaz et al.: Optimization of self-assembling properties of fatty acids grafted to methoxy poly(ethylene glycol) as nanocarriers for etoposide, Acta Pharm. 62 (2012) 31-44.

\section{Fourier transform infrared spectroscopy}

Infrared spectra of polymers were measured on an FTIR spectrometer (Rayleigh, WQF-510/520, China) at wavenumbers $500-4000 \mathrm{~cm}^{-1}$ with a resolution of $4 \mathrm{~cm}^{-1}$ using the $\mathrm{KBr}$ disc method.

\section{Nuclear magnetic resonance spectroscopy}

Two mg of mPEG-Ma was dissolved in $0.5 \mathrm{~mL}$ of chloroform while mPEG-Sa and mPEG-Ba (2 mg) were dissolved in $0.5 \mathrm{~mL}$ of DMSO. The ${ }^{1} \mathrm{H}$ NMR analysis was carried out on a Bruker ARX 400-MHz (Germany) instrument.

\section{Experimental design}

Studied variables were: the type of fatty acid and the amount of drug per $100 \mathrm{mg}$ of copolymer while the studied responses were particle size, zeta potential, loading efficiency of etoposide in the micelles and drug release efficiency from mPEG-fatty acids. Each variable was studied at three levels. The levels were selected in accordance with preliminary studies (data not shown). D-optimal criteria, one of several »alphabetic" optimalities, were developed to select design points in such a way to minimize the variance associated with the estimates of specified model coefficients. Central composite design (CCD) is widely applied in many fields to construct a second-order response surface model with quantitative factors to help increase the precision of the estimated model. When an experiment also includes qualitative factors, the effects between quantitative and qualitative factors should be taken into consideration. It is shown that, at each qualitative level, the corresponding D-optimal design also consists of three portions as $\mathrm{CCD}$, i.e., the cube design, the axial design and center points, but with different weights. The reasons for using D-optimal designs instead of standard classical designs generally fall into two categories: (i) standard factorial or fractional factorial designs require too many runs for the amount of resources or time allowed for the experiment, and (ii) the design space is constrained (process space contains factor settings that are not feasible or are impossible to run). D-optimal designs are a form of design provided by a computer algorithm. These types of computer-aided designs are particularly useful when classical designs do not apply. Unlike standard classical designs such as factorials and fractional factorials, D-optimal design matrices are usually not orthogonal and effect estimates are correlated. A D-optimal design minimizes the determinant of the $\left(\mathrm{X}^{\prime} \mathrm{X}\right)^{-1}$ matrix. This will minimize the volume of the confidence ellipsoid for the coefficients. Equivalently, D-optimality maximizes the determinant $\left(\mathrm{X}^{\prime} \mathrm{X}\right)$, which is called the »information « matrix. The key is that these designs are built algorithmically to provide the most accurate estimates of the model coefficients (13).

The design matrix was built and analyses were performed by the statistical software package Design-Expert (version 7.0.0, Stat-Ease, Inc., Minneapolis, MN, USA). Table I shows the factors and different formulations of micelles. Some formulations are repeated as checking points in the design. In this study, all experiments were performed in triplicate and the averages were considered as response(s). The significance of the effect of independent variables on the response was evaluated by ANOVA through Fisher's test and shown by $p<0.05$. 
J. Varshosaz et al.: Optimization of self-assembling properties of fatty acids grafted to methoxy poly(ethylene glycol) as nanocarriers for etoposide, Acta Pharm. 62 (2012) 31-44.

Table I. Formulation of different micelles prepared according to the 2-factor, 3-level D-optimal design

\begin{tabular}{cll}
\hline $\begin{array}{c}\text { Etoposide } \\
\text { \% in copolymer })\end{array}$ & Fatty acid type & Micelle formulation \\
\hline 5.0 & Myristic acid & mPEG-Ma $_{5}{ }^{\mathrm{a}}$ \\
5.0 & Myristic acid & mPEG-Ma $_{5}{ }^{\mathrm{a}}$ \\
7.5 & Myristic acid & mPEG-Ma $_{7.5}$ \\
10.0 & Myristic acid & mPEG-Ma $_{10}$ \\
15.0 & Myristic acid & mPEG-Ma $_{15}{ }^{\mathrm{a}}$ \\
15.0 & Myristic acid & mPEG-Ma $_{15}{ }^{\mathrm{a}}$ \\
5.0 & Stearic acid & mPEG-Sa $_{5}{ }^{\mathrm{a}}$ \\
5.0 & Stearic acid & mPEG-Sa $_{5}{ }^{\mathrm{a}}$ \\
7.5 & Stearic acid & mPEG-Sa $_{7.5}$ \\
10.0 & Stearic acid & mPEG-Sa $_{10}$ \\
15.0 & Stearic acid & mPEG-Sa $_{15}{ }^{\mathrm{a}}$ \\
15.0 & Stearic acid & mPEG-Sa $_{15}{ }^{\mathrm{a}}$ \\
5.0 & Behenic acid & mPEG-Ba $_{5}$ \\
7.5 & Behenic acid & mPEG-Ba $_{7.5}$ \\
10.0 & Behenic acid & mPEG-Ba $_{10}$ \\
15.0 & Behenic acid & mPEG-Ba $_{15}{ }^{\mathrm{a}}$ \\
15.0 & Behenic acid & mPEG-Ba $_{15}{ }^{\mathrm{a}}$ \\
\hline & & \\
\hline
\end{tabular}

a Repeated formulations are check points proposed by the Design Expert software in D-Optimal Design.

Preparation of self-assembled micelle nanoparticles of the mPEG-fatty acid conjugate and measuring the $\mathrm{CMC}$

In general, the hydrophobic fatty acid segment of the mPEG-fatty acid molecule was self-associated as a hydrophobic core, while the hydrophilic mPEG segments were pushed into the aqueous phase surrounding the core to form micelles. Self-aggregation behavior of mPEG-fatty acid in aqueous medium was determined by the dye solubilization method using pyrene as a probe molecule. Pyrene fluorescence probing is a widely used methodology for measuring the CMC of micelles. This method is based on changes in the intensity of the vibrational bands of pyrene solubilized in water and in micellar medium. Emission spectra of pyrene strongly depend on microenvironment polarity; in a polar solvent, the intensity of the first energy band (377 nm, $\left.I_{1}\right)$ is higher than the third energy band $\left(390 \mathrm{~nm}, I_{3}\right)$ of the pyrene emission spectra while in a hydrophobic environment the intensity of $I_{3}$ is higher than that of $I_{1}$. Therefore, when micelles are formed in aqueous medium, the pyrene is preferably partitioned into the hydrophobic core and the intensity of $I_{3}$ increases. As a result, the ratio of $I_{1} / I_{3}$ can be used to determine CMC.

Fifty $\mathrm{mg}$ of dry powder of the m-PEG-fatty acid conjugate was dissolved in $50 \mathrm{mg}$ of $0.1 \mathrm{~mol} \mathrm{~L}^{-1}$ phosphate buffer solution (PBS) prepared from $\mathrm{KH}_{2} \mathrm{PO}_{4}(\mathrm{pH} 7.4)$ as the stock solution and sonicated for $30 \mathrm{~min}$ to get an optically clear solution. The critical micellar concentration of mPEG-fatty acid was determined using pyrene as a hydropho- 
bic fluorescence probe. CMC was determined based on the intensity of pyrene excitation spectra and shift of the spectra with increasing mPEG-fatty acid concentration. A pyrene solution $\left(6 \times 10^{-6} \mathrm{~mol} \mathrm{~L}^{-1}\right)$ in acetone was added to the test tube and evaporated to remove the solvent. Solution of mPEG-fatty acid micelles in PBS (pH 7.4) was then added to the test tube in concentration ranging from 0.001 to $1 \mathrm{mg} \mathrm{mL}^{-1}$, bringing the final concentration of pyrene to $6.0 \times 10^{-7} \mathrm{~mol} \mathrm{~L}^{-1}$. The solution was vortexed and kept overnight at $37{ }^{\circ} \mathrm{C}$ to equilibrate pyrene with the micelles (14). Measurements of fluorescence intensity were carried out at $\lambda_{\mathrm{ex}}=334 \mathrm{~nm}$ and $\lambda_{\mathrm{em}}=377$ and $390 \mathrm{~nm}$. The change in the ratio of fluorescence intensity $\left(I_{377} / I_{390}\right)$ of pyrene with the log (concentration) of mPEG-fatty acid was recorded for determining CMC.

\section{Particle size and zeta potential of micelles}

Size and distribution of the micelles were measured by the dynamic light scattering method (DLS, Zetasizer ZEN3600, Malvern Instruments Ltd., UK). The test was performed at $25^{\circ} \mathrm{C}$ at a scattering angle of $90^{\circ}$. Prior to measurements, the micelle solution (1.0 $\mathrm{mg} \mathrm{mL}{ }^{-1}$ ) was passed through a $0.45-\mu \mathrm{m}$ pore size filter.

\section{Hydrophilic-lipophilic balance (HLB) values of the mPEG-fatty acid conjugate}

The HLB value of copolymers was measured using the relative molecular mass of mPEG-fatty acid conjugates as reported by Pasquali et al. (15).

\section{Phase solubility}

Phase solubility analysis was carried out according to the method described by Higuchi and Connors (16). Excess of the drug was added separately into a screw-capped vial containing $100 \mathrm{mg}$ of $\mathrm{mPEG}$-fatty acid in PBS. The vial was shaken for 48 hours in an orbital water bath (Daiki Sciences Co, Korea) at $25{ }^{\circ} \mathrm{C}$ and allowed to stand for 24 hours to attain equilibrium. Solutions were filtered using a nylon membrane filter of $0.45 \mu \mathrm{m}$ pore size. The $\mathrm{pH}$ of the filtered solution was checked. The sample was diluted appropriately with PBS and analyzed in a UV Visible spectrophotometer (UV mini 1240, Shimadzu, Japan) at $283.5 \mathrm{~nm}$.

\section{Encapsulation of etoposide in micellar nanoparticles}

The encapsulation efficiency of etoposide was studied at different etoposide concentrations and different types of fatty acids used to synthesize mPEG-fatty acid copolymers. Etoposide solution in acetone was added to the solution of mPEG-fatty acid in acetone to obtain different drug to polymer ratios ranging from 1:20 to 3:20.

Acetone was evaporated under vacuum to produce a film consisting of an mPEG-fatty acid/etoposide mixture. Micelles were formed by extensive vortexing of the film in PBS ( $\mathrm{pH}$ 7.4). Nonencapsulated etoposide was separated by centrifugation (Eppendorf 5430 centrifuge, Germany) of the micelle suspension at $6720 \times g$ for $5 \mathrm{~min}$ in Amicon ultra centrifugal filter Eppendorf tubes (Millipore Ireland, cut-off $10000 \mathrm{Da}$ ) and quantified spectrophotometrically at $283.5 \mathrm{~nm}$. 
J. Varshosaz et al.: Optimization of self-assembling properties of fatty acids grafted to methoxy poly(ethylene glycol) as nanocarriers for etoposide, Acta Pharm. 62 (2012) 31-44.

\section{In vitro drug release from etoposide-loaded polymeric micelles}

To determine the release rate of etoposide from nanoparticles, $5 \mathrm{~mL}$ of an aqueous dispersion of each formulation was added to a dialysis bag with molecular mass cut-off of $12400 \mathrm{Da}$ and sealed bags were placed in a glass test-tube in $50 \mathrm{~mL}$ of PBS $0.1 \mathrm{~mol} \mathrm{~L}^{-1}$ ( $\mathrm{pH}$ 7.4) under agitation. Samples of $0.5 \mathrm{~mL}$ were withdrawn at predetermined time points and were immediately replaced with fresh PBS maintained at the same temperature. The content of etoposide in the samples was determined.

\section{RESULTS AND DISCUSSION}

\section{Synthesis and characterization of mPEG-fatty acid copolymers}

The mPEG-Ma, mPEG-Sa and mPEG-Ba block copolymers were synthesized by a single-step reaction of $\mathrm{mPEG}$ with myristoyl chloride, stearoyl chloride and behenoyl chloride, respectively. They reacted with the hydroxyl group of mPEG to provide an ester linkage. The structure of MPEG-fatty acid block copolymers was characterized by ${ }^{1} \mathrm{H}$ NMR and FTIR. Figs. 1a-c show the ${ }^{1} \mathrm{H}$ NMR spectra of mPEG-Ma, mPEG-Sa and mPEG-Ba, respectively. In the ${ }^{1} \mathrm{H}$ NMR spectra of mPEG-Ma (Fig. 1a), the characteristic chemical shifts of mPEG were $3.56 \mathrm{ppm}$ (d) and $3.28 \mathrm{ppm}$ (c) due to the methylene protons of PEG oxyethylene unit and protons of the methoxy end group, respectively. Coupling of the myristate residue to $\mathrm{mPEG}$ was characterized by signals at $2.25 \mathrm{ppm}$ (a), $1.55 \mathrm{ppm}$ (b) and $4.13 \mathrm{ppm}$ (e). Fig. 1b relates to the mPEG-Sa conjugate, which shows the characteristic chemical shifts of mPEG at 3.51 ppm (d) and 3.24 ppm (c) due to methylene protons of PEG oxyethylene units and protons of the methoxy end group, respectively. Coupling of the stearate residue to $\mathrm{MPEG}$ was characterized by signals at $2.28 \mathrm{ppm}$ (a), $1.51 \mathrm{ppm}$ (b) and $4.11 \mathrm{ppm}$ (e). Fig. 1c shows the ${ }^{1} \mathrm{H}$ NMR spectrum of the MPEG-Ba block copolymer. In the ${ }^{1} \mathrm{H}$ NMR spectra, the characteristic chemical shifts of mPEG were at $3.54 \mathrm{ppm}$ (d) and $3.36 \mathrm{ppm}$ (c) due to methylene protons of PEG oxyethylene unit and protons of the methoxy end group, respectively. Coupling of the residue to mPEG was characterized by signals at $2.20 \mathrm{ppm}(\mathrm{a}), 1.48 \mathrm{ppm}$ (b) and $4.06 \mathrm{ppm}$ (e). From the peak integrity ratio of the methylene groups, the molar ratios of repeating units in mPEG and Ma, Sa and Ba blocks could be calculated.

The FTIR spectra of mPEG-Ma, mPEG-Sa and mPEG-Ba are seen in Figs. 2a-c, respectively. The FTIR spectrum of conjugates shows a sharp peak due to the stretching vi-

Table II. Properties of polymers used in micelle preparation

\begin{tabular}{ccccc}
\hline $\begin{array}{c}\mathrm{CMC} \\
\left(\mathrm{mg} \mathrm{mL}^{-1}\right)\end{array}$ & $\begin{array}{c}\text { Hydrophilic-lipophilic } \\
\text { balance (HLB) value }\end{array}$ & $\begin{array}{c}\text { Etoposide solubility in } \\
\text { PBS }(\mathrm{pH} 7.4)\left(\mu \mathrm{mL}^{-1}\right)\end{array}$ & $M_{\mathrm{r}}$ & Copolymer \\
\hline 128 & 10.56 & 87 & 761.32 & mPEG-Ma \\
99 & 8.25 & 90 & 817.43 & mPEG-Sa \\
80 & 5.93 & 94 & 873.54 & mPEG-Ba \\
\hline
\end{tabular}


J. Varshosaz et al.: Optimization of self-assembling properties of fatty acids grafted to methoxy poly(ethylene glycol) as nanocarriers for etoposide, Acta Pharm. 62 (2012) 31-44.

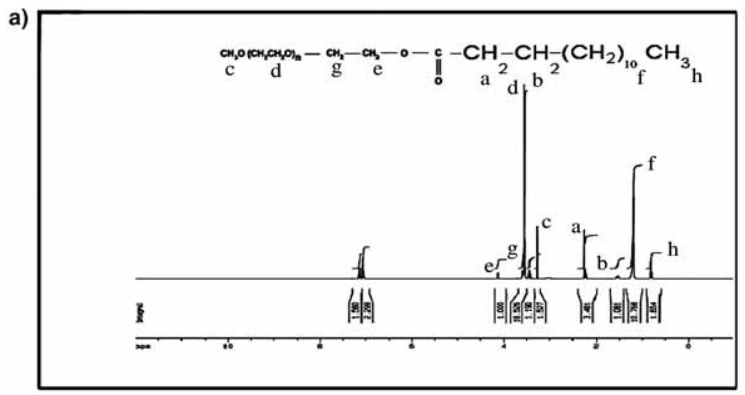

b)
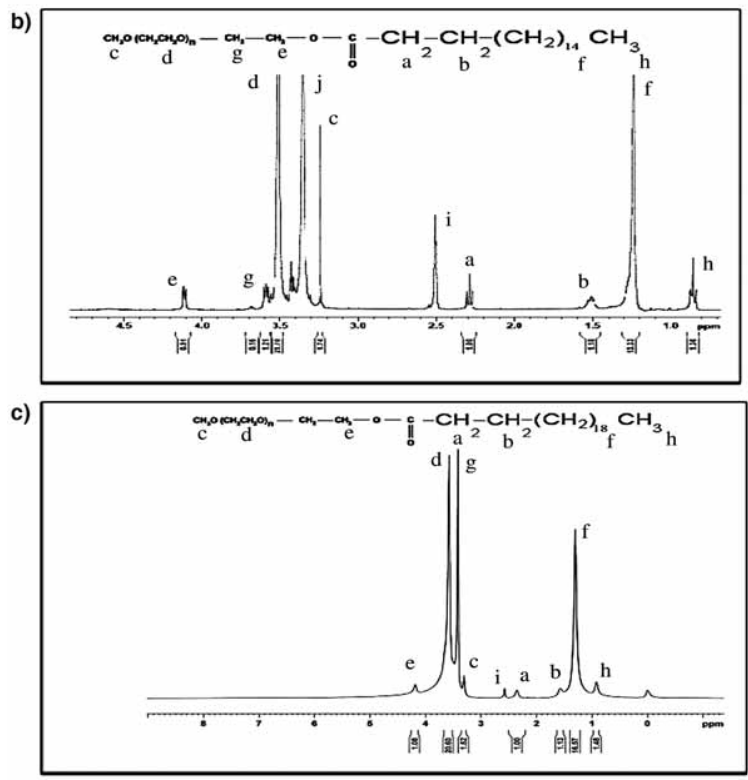

Fig. 1. ${ }^{1} \mathrm{H}$ NMR of: a) mPEG-myristic acid (mPEG-Ma), b) mPEG-stearic acid (mPEG-Sa), and c) mPEG-behenic acid (mPEG-Ba) copolymer.

bration of the ester bond: mPEG-Ma conjugate shows a sharp peak at $1738 \mathrm{~cm}^{-1}$ (Fig. 2a), mPEG-Sa at $1732 \mathrm{~cm}^{-1}$ (Fig. 2b) and mPEG-Ba at $1730 \mathrm{~cm}^{-1}$ (Fig. 2c). These peaks were not present in the spectrum of $\mathrm{MPEG}$, which confirms the formation of IPEG-Ma, mPEG-Sa and mPEG-Ba conjugations via ester linkage.

\section{Drug solubility in micelles and HLB}

Table II shows the results of measuring etoposide solubility in micelles and the HLB values of copolymers. Theoretic $M_{\mathrm{r}}$ of the copolymers is also shown in that table. As the results show, mPEG-Ma has the lowest $M_{\mathrm{r}}$ and the highest HLB and CMC values. Etoposide solubility in PBS in the presence of three copolymers shows that mPEG-Ba solu- 
bilizes etoposide $\left(94 \mu \mathrm{g} \mathrm{mL}^{-1}\right)$ more than the other two copolymers $\left(90\right.$ and $87 \mu \mathrm{g} \mathrm{mL}^{-1}$ for mPEG-Sa and mPEG-Ma, respectively) compared to the solubility of the drug in PBS without copolymers (around $60 \mu \mathrm{g} \mathrm{mL}^{-1}$ ). This indicates a high increase in etoposide solubility in the presence of prepared surfactant copolymers.

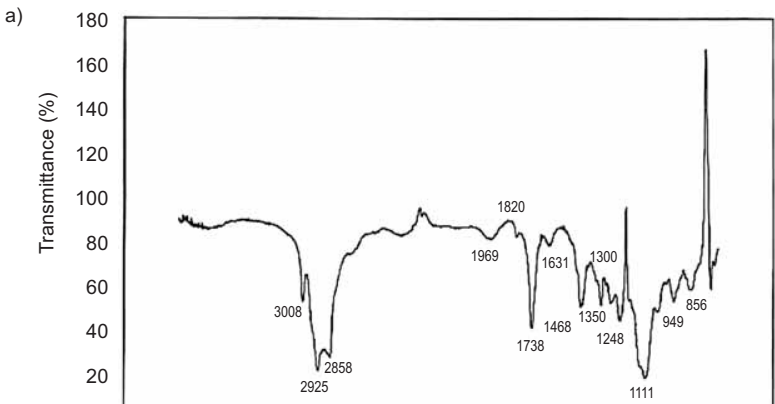

$390036003300300027002400 \quad 2100 \quad 1800 \quad 1500 \quad 900 \quad 1200 \quad 600$

Wavenumber $\left(\mathrm{cm}^{-1}\right)$
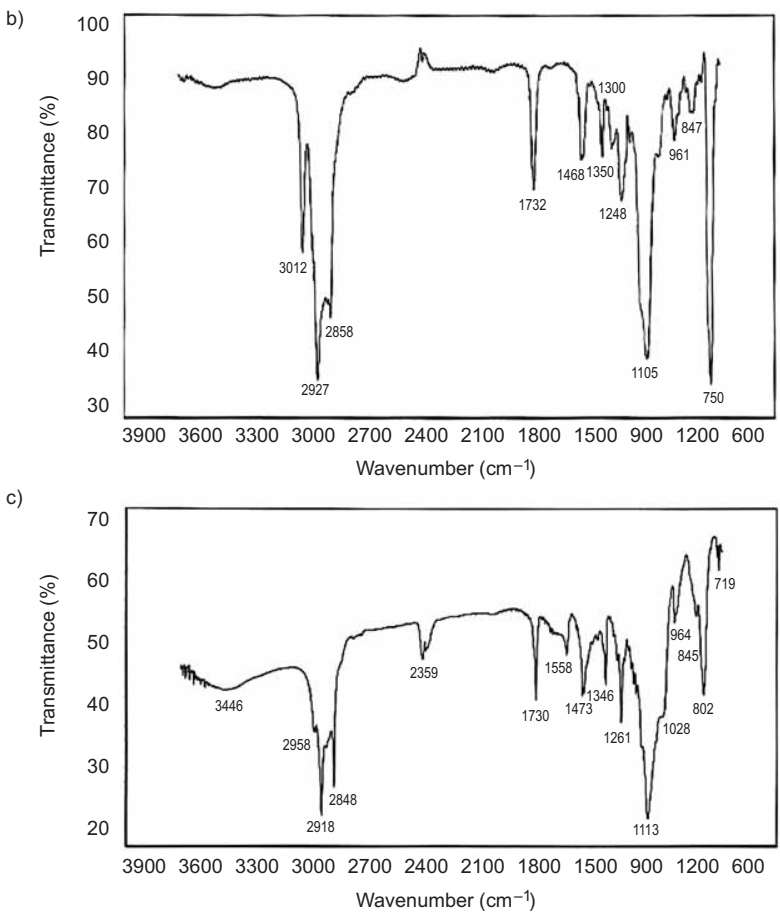

Fig. 2. FTIR spectra of: a) mPEG-myristic acid (mPEG-Ma), b) mPEG-stearic acid (mPEG-Sa), and c) mPEG-behenic acid (mPEG-Ba) copolymer. 
J. Varshosaz et al.: Optimization of self-assembling properties of fatty acids grafted to methoxy poly(ethylene glycol) as nanocarriers for etoposide, Acta Pharm. 62 (2012) 31-44.

\section{Experimental design and validation}

First, the number of factors and levels for optimization of etoposide-loaded micelles were selected. To achieve optimum conditions meaning minimum particle size, maximum drug loading and release efficiency, a surface response study based on D-optimal design (14) was employed and the variables applied were: type of fatty acid with different chain length and percent of drug in the copolymer. They were evaluated in 17 experiments (Table I). Some of the repeated runs seen in Table I were selected by the software as check points. As can be seen, the range of particle size in designed runs was $13-480 \mathrm{~nm}$, zeta potential was between -0.1 and $-7.5 \mathrm{mV}$, drug loading was between 36 and $54 \%$ and release efficiency until $5 \mathrm{~h}$ was between 39 and $52 \%$ (Table III).

Multiple coefficients of determination and adjusted $R^{2}$ were used as quality indicators to evaluate the fitness of the second-order polynomial equations for calculating the particle size, loading efficiency and release efficiency of etoposide from the micelles. The similarity between $R^{2}$ for loading efficiency $\left(R^{2}=0.8582\right)$ and adjusted $R^{2}$ values $\left(R^{2}=0.7938\right)$ and also for other studied responses shows the adequancy of the model to predict the response.

Table III. Physical properties, loading efficiency and release characteristics of 17 formulations of micelles prepared by the D-optimal design

\begin{tabular}{|c|c|c|c|c|c|}
\hline Copolymer & Size $(\mathrm{nm})$ & $\begin{array}{l}\text { Polydispersity } \\
\text { index }\end{array}$ & $\begin{array}{l}\text { Zeta potential } \\
(\mathrm{mV})\end{array}$ & $\begin{array}{c}\text { Loading } \\
\text { efficiency (\%) }\end{array}$ & $R E_{5}(\%)^{\mathrm{a}}$ \\
\hline mPEG-Ma ${ }_{5}^{\mathrm{b}}$ & $18.4 \pm 1.0$ & $0.4 \pm 0.1$ & $-7.4 \pm 1.6$ & $54.0 \pm 2.6$ & $49.1 \pm 2.3$ \\
\hline mPEG-Ma ${ }_{5}^{\mathrm{b}}$ & $12.9 \pm 0.4$ & $0.5 \pm 0.0$ & $-4.3 \pm 1.5$ & $52.0 \pm 3.0$ & $43.8 \pm 2.5$ \\
\hline mPEG-Ma 7.5 & $48.5 \pm 0.9$ & $1.0 \pm 0.0$ & $0.9 \pm 0.1$ & $51.0 \pm 3.0$ & $53.3 \pm 1.6$ \\
\hline mPEG-Ma 10 & $13.6 \pm 5.4$ & $0.4 \pm 0.1$ & $-3.2 \pm 2.5$ & $50.9 \pm 3.2$ & $39.3 \pm 0.6$ \\
\hline mPEG-Ma ${ }_{15}{ }^{b}$ & $13.4 \pm 2.2$ & $0.4 \pm 0.1$ & $-3.0 \pm 1.3$ & $44.0 \pm 1.7$ & $45.8 \pm 2.7$ \\
\hline mPEG-Ma ${ }_{15}{ }^{b}$ & $32.8 \pm 2.2$ & $0.6 \pm 0.1$ & $-5.3 \pm 0.5$ & $45.0 \pm 3.0$ & $43.2 \pm 0.6$ \\
\hline mPEG-Sa ${ }_{5}{ }^{b}$ & $175.8 \pm 12.0$ & $0.7 \pm 0.3$ & $-2.0 \pm 1.0$ & $51.0 \pm 2.6$ & $46.8 \pm 3.0$ \\
\hline mPEG-Sa ${ }_{5}{ }^{b}$ & $235.4 \pm 27.0$ & $0.6 \pm 0.1$ & $-2.1 \pm 0.1$ & $52.0 \pm 3.5$ & $38.9 \pm 1.1$ \\
\hline mPEG-Sa 7.5 & $67.6 \pm 7.1$ & $1.0 \pm 0.0$ & $-0.8 \pm 1.1$ & $44.0 \pm 2.6$ & $48.2 \pm 1.8$ \\
\hline mPEG-Sa ${ }_{10}$ & $219.7 \pm 8.6$ & $0.6 \pm 0.2$ & $-1.5 \pm 0.9$ & $39.0 \pm 4.0$ & $49.6 \pm 1.6$ \\
\hline mPEG-Sa ${ }_{15}{ }^{b}$ & $45.0 \pm 3.7$ & $0.5 \pm 0.2$ & $-6.3 \pm 1.3$ & $38.0 \pm 3.6$ & $46.0 \pm 1.1$ \\
\hline mPEG-Sa ${ }_{15}{ }^{b}$ & $70.9 \pm 1.4$ & $0.5 \pm 0.2$ & $0.0 \pm 0.1$ & $36.0 \pm 3.0$ & $51.1 \pm 4.6$ \\
\hline mPEG-Ba 5 & $478.9 \pm 58.0$ & $0.6 \pm 0.1$ & $-7.3 \pm 0.4$ & $49.0 \pm 2.6$ & $41.8 \pm 1.8$ \\
\hline mPEG-Ba 7.5 & $39.0 \pm 0.2$ & $0.4 \pm 0.1$ & $0.0 \pm 0.1$ & $44 \pm 3.4$ & $58.8 \pm 1.2$ \\
\hline mPEG-Ba 10 & $146.0 \pm 2.6$ & $0.3 \pm 0.0$ & $1.3 \pm 0.7$ & $51.0 \pm 3.6$ & $52.1 \pm 9.9$ \\
\hline mPEG-Ba ${ }_{15}{ }^{b}$ & $119.7 \pm 1.8$ & $0.5 \pm 0.1$ & $-0.1 \pm 1.1$ & $48.0 \pm 2.0$ & $41.3 \pm 5.4$ \\
\hline mPEG-Ba $a_{15}{ }^{b}$ & $118.9 \pm 3.9$ & $0.33 \pm 0.06$ & $-1.5 \pm 1.0$ & $52.0 \pm 2.7$ & $49.1 \pm 1.1$ \\
\hline
\end{tabular}

a Calculated release efficiency (\%) over $5 \mathrm{~h}$.

$\mathrm{b}$ Repeated formulations are check points proposed by the Design Expert software in D-Optimal Design. Mean \pm SD $(n=3)$. 
Optimal points were determined considering the goals to minimize the particle size and to maximize drug loading and release efficiency. Design Expert software introduced the optimum values of independent variables as $5 \%$ drug in the mPEG-Ma of copolymer.

In order to validate the experimental model, three verification experiments were performed using statistically optimized variables. Under these conditions, the predicted value for particle size of micelles was about $11 \mathrm{~nm}$, loading efficiency of $52.8 \%$ and release efficiency of $49.8 \%$, which are close to the values reported for actual values of these responses in Table III (mPEG-Ma $)$. The perfect agreement between the observed and predicted values confirms the validity and precision of the model.

\section{Micelle formation}

The CMC of micelles was determined from the curve (Fig. 3) showing the relationship between changes in pyrene intensity $\left(I_{377} / I_{390}\right)$ with the concentration of mPEG-fatty acid. At low concentrations, the ratio of fluorescence intensity values reduces markadly, but with continuing increase of mPEG-fatty acid concentration the ratio of intensity begins to become constant, implying the onset of self-assembly.

The CMC was calculated from the crossover point and its values for mPEG-Ma, mPEG-Sa and mPEG-Ba were 128, 99 and $80 \mu \mathrm{g} \mathrm{mL}-1$, respectively (Table II). This is about 18-23 times lower than that of low molecular mass surfactant micelles like sodium dodecyl sulphate with $\mathrm{CMC}$ of $2.3 \mathrm{mg} \mathrm{mL}^{-1}$ (17). It means that the prepared copolymers can form micelles under highly diluted conditions.

The low CMC values indicate the thermodynamic stability of micelles (17). The CMC values became lower with the increased molecular mass of the fatty acid block, indicating that the longer hydrophobic chain helped form more stable micelles (18). According to the above CMCs, mPEG-Sa and mPEG-Ba copolymers were more stable than mPEG-Ma copolymers because of the longer chain of fatty acids. Rosen (19) has also shown that in aqueous medium the CMC decreases as the number of carbon atoms in the hy-

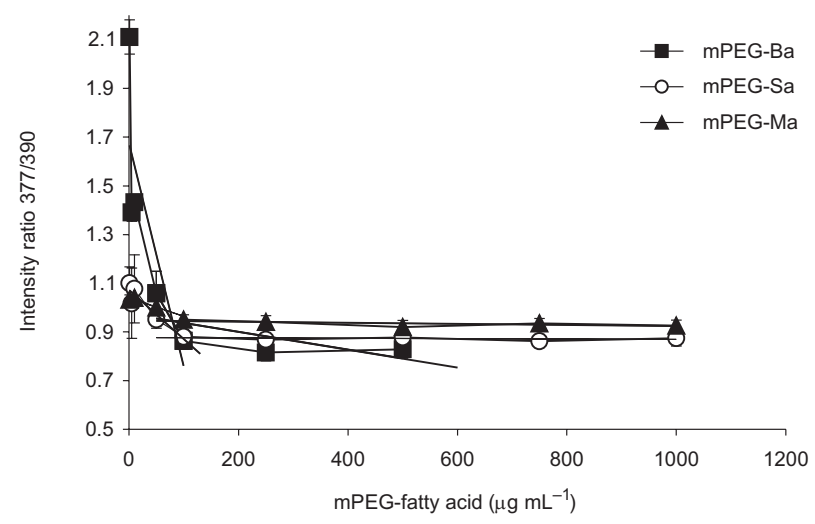

Fig. 3. Plot of flurescence intensity ratio $(377 \mathrm{~nm} / 390 \mathrm{~nm})$ of pyrene $v$ s. concentration of mPEG-fatty acid copolymers. The results are mean $\pm \mathrm{SD}(n=3)$. 
J. Varshosaz et al.: Optimization of self-assembling properties of fatty acids grafted to methoxy poly(ethylene glycol) as nanocarriers for etoposide, Acta Pharm. 62 (2012) 31-44.

drophobic group increases to about 16, and a general rule for ionic surfactants is that the CMC halves by the addition of one methylene group to a straight chain hydrophobic group attached to a single terminal hydrophilic group. For nonionics and zwitterionics, the decrease of CMC with an increase in the hydrophobic group is somewhat larger. When the number of carbon atoms in a straight chain hydrophobic group exceeds 16 , the $\mathrm{CMC}$ no longer decreases so rapidly with increasing the length of the chain, and when the chain exceeds 18 carbons, it may remain substantially unchanged with further increase in chain length. This may be due to the coiling of these long chains in water.

\section{Micelle size and loading of etoposide in the micelles}

Mean diameters for loaded micelles are shown in Table III. According to this table, the mPEG-Ma copolymer loaded with $5 \%$ etoposide has the smallest particle size (about $13 \mathrm{~nm}$ ), and mPEG-Ba loaded also with $5 \%$ etoposide has the biggest particle size (about $479 \mathrm{~nm}$ ). In other words, by increasing the hydrophohic chain length of micelles, their particle size increased as well.

When the effect of each variable on the loading efficiency of etoposide in the micelles is studied, one may conclude that the lowest loading efficiency is seen in mPEG-Sa micelles while mPEG-Ma shows the highest loading efficiency, possibly due to the closer solubility parameter between the drug and the core of the micelles. The Hildebrand solubility parameter $(\delta)$ provides a numerical estimate of the degree of interaction between materials and can be a good indication of solubility, particularly for nonpolar materials such as many polymers. Materials with similar values of $\delta$ are likely to be miscible (20). Increasing the drug/polymer ratio reduced the loading efficiency in Ma and Sa micelles while this relationship was reverse in Ba. A possible reason may be the size of the core of the micelles, which in $\mathrm{Ma}$ and $\mathrm{Sa}$ are lower than Ba. By increasing the drug ratio they cannot accommodate the loading drug in the core and consequently the drug payload will reduce, while in Ba micelles the core has enough space to keep increasing amounts of the drug, causing a positive relationship between the drug/copolymer ratios with the loading efficiency.

\section{In vitro release of etoposide from loaded micelles}

Fig. 4 shows in vitro release of etoposide from mPEG-Ma, mPEG-Sa, mPEG-Ba micelles with different drug loadings. The drug release from each formulation was observed for $5 \mathrm{~h}$. As it can be seen from Fig. 4, percent drug released at the end of the last sampling time (i.e., at the end of $5 \mathrm{~h}$ ) for different micellar formulations changes between about $70 \%$ (for $\mathrm{mPEG}-\mathrm{Ba}_{5}$ ) to $90 \%$ (for $\mathrm{mPEG}-\mathrm{Ma}_{7.5}$ ). To include all release data, release efficiency percent until $5 \mathrm{~h}\left(\mathrm{RE}_{5}, \%\right)$, which is a model independent parameter, was calculated from the area under the release curve until $5 \mathrm{~h}$, expressed as percentage of the curve at maximum release (i.e., $100 \%$ drug release) over the same time period (Table III). The main adventage of using RE is that no reference batch is needed and the result is closely related to the release behavior of micelles. As it is shown in Table III, $\mathrm{RE}_{5}$ (\%) changes between $38.9 \%$ (for mPEG-Sa 5 ) and $58.8 \%$ (for PEG-Ba 7.5 ). This model independent parameter shows how efficiently the micelles can release the drug over the sampling time in the release test. When each studied variable is considered, the micelles 


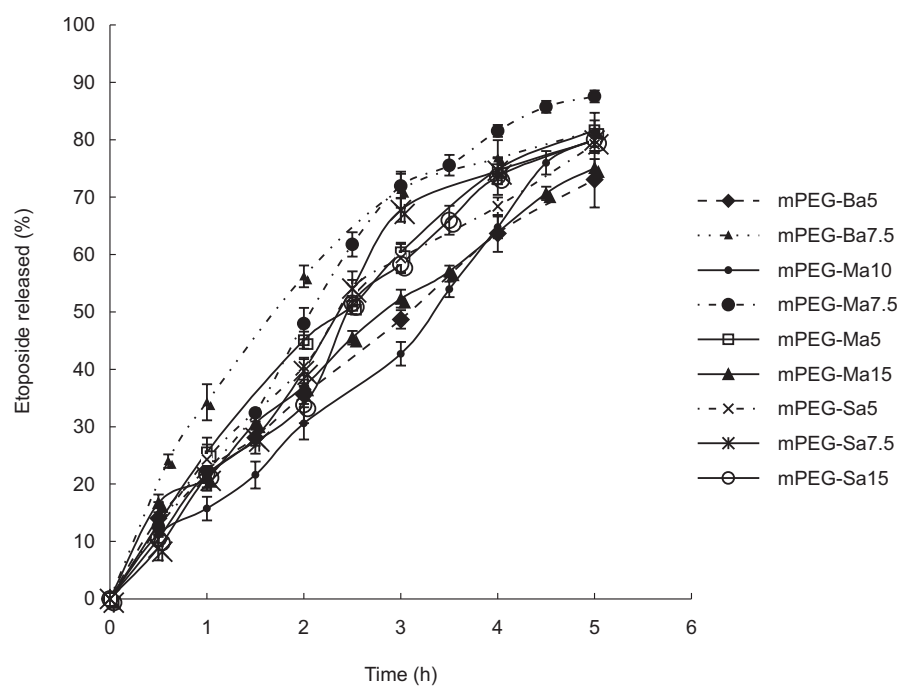

Fig. 4. In vitro etoposide release profiles from different formulations of mPEG-Ma, mPEG-Sa and mPEG-Ba micelles at $\mathrm{pH}$ 7.4. The results are mean $\pm \mathrm{SD}(n=3)$.

of Ma showed lower drug release compared to Sa and $\mathrm{Ba}$, which may be due to higher similarity of the solubility parameter (as defined earlier) of the drug to the core of the Ma micelles causing, tighter entrapment of the drug and higher partitioning of etoposide in these micelles compared the other two fatty acids. On the other hand, the effect of the other variable, i.e., the drug/polymer ratio, shows the highest release efficiency related to $7.5 \%$ drug in the copolymers. However, the combination effect of the two variables, as can be seen in Table III, is that the micelles of $\mathrm{mPEG}-\mathrm{Ba}_{7.5}$ have higher release efficiency than other studied formulations and $\mathrm{mPEG}_{-} \mathrm{Sa}_{5}$ have the lowest release efficiency.

\section{CONCLUSIONS}

Amphiphilic block copolymers of mPEG-Ma, mPEG-Sa, mPEG-Ba formed micelles in aqueous solution. The advantage of these conjugates is that they can be synthesized in a single-step reaction and the CMC values of the copolymers are low. These low CMC values indicate their ability to form stable micelles and keep their intact structure upon dilution with body fluids. Increasing in hydrophobic chain length of fatty acids used in the formation of micelles caused a decrease of $\mathrm{CMC}$ values and greater encapsulation of etoposide in the hydrophobic core of the micelles, and meanwhile enhanced the drug solubility. The mPEG-Ma ${ }_{5}$ copolymer, with the lowest drug to polymer ratio of $1 / 20$, had higher loading efficiency compared to other ratios. The size of the prepared micelles was generally between 12 and $150 \mathrm{~nm}$, which can prevent the risk of embolism upon parenteral administration. The mPEG-Ma copolymer micelles had the smallest particle 
J. Varshosaz et al.: Optimization of self-assembling properties of fatty acids grafted to methoxy poly(ethylene glycol) as nanocarriers for etoposide, Acta Pharm. 62 (2012) 31-44.

size due to smaller hydrophobic fatty acid chain compared to other fatty acids. The in vitro release of etoposide from drug-loaded micelles was generally about 80 percent of the loaded drug within $5 \mathrm{~h}$. This release pattern shows a suitable system for middle-term drug delivery. The optimum conditions for the production of etoposide micelles were obtained with $5 \%$ drug in mPEG-Ma. These micelles showed the smallest particle size and maximum drug loading and drug release efficiency.

\section{REFERENCES}

1. S. R. Croy and G. S. Kwon, Polymeric micelles for drug delivery, Curr. Pharm. Des. 12 (2006) 4669-4684; DOI: 10.2174/138161206779026245.

2. J. L. Mura and G. Riess, Polymeric surfactants in latex technology: polystyrene-poly(ethylene oxide) block copolymers as stabilizers in emulsion polymerization, Polym. Adv. Technol. 6 (1995) 497-508; DOI: 10.1002/pat.1995.220060711.

3. R. Nagarajan, Solubilization in aqueous solutions of amphiphiles, Curr. Opin. Colloid Interf. Sci. 1 (1996) 391-401; DOI: 10.1016/s1359-0294(96)80139-7.

4. S. Kim, J. Y. Kim, K. M. Huh, G. Acharya and K. Park, Hydrotropic polymer micelles containing acrylic acid moieties for oral delivery of paclitaxel, J. Control. Release 132 (2008) 222-229; DOI: 10.1016/j.jconrel.2008.07.004.

5. G. S. Kwon and K. Kataoka, Block copolymer micelles as long-circulating carriers for delivery of therapeutic and diagnostic agents, Adv. Drug Deliv. Rev. 16 (1995) 295-309; DOI: 10.1016/0169$-409 x(95) 00031-2$.

6. K. Kataoka, A. Harada and Y. Nagasaki, Block copolymer micelles for drug delivery: design, characterization and biological significance, Adv. Drug Deliv. Rev. 47 (2001) 113-131; DOI: 10.1016/ s0169-409x(00)00124-1.

7. R. Savic, L. Luo, A. Eisenberg and D. Maysinger, Micellar nanocontainers distribute to defined cytoplasmic organelles, Science 300 (2003) 615-618; DOI: 10.1126/science.1978192.

8. G. Gaucher, M. H. Dufresne, V. P. Sant, N. Kang, D. Maysinger and J. C. Leroux, Block copolymer micelles: preparation, characterization and application in drug delivery, J. Control. Release 109 (2005) 169-188; DOI: 10.1016/j.jconrel.2005.09.034.

9. M. Chamberlain, Recurrent brainstem gliomas treated with oral VP-16, J. Neurooncol. 15 (1993) 133-139.

10. D. Ashley, L. Meier and T. Kerby, Response of recurrent medulloblastoma to low-dose oral etoposide, J. Clin. Oncol. 14 (1996) 1922-1927.

11. L. H. Reddy, J. S. Adhikari, B. S. R. Dwarakanath, R. K. Sharma and R. R. Murthy, Tumoricidal effects of etoposide incorporated into solid lipid nanoparticles after intraperitoneal administration in Dalton's lymphoma bearing mice, AAPS J. 8 (2006) E254-E262; DOI: 10.1208/aapsj080229.

12. A. Sahu, U. Bora, N. Kasoju and P. Goswami, Synthesis of novel biodegradable and self-assembling methoxy poly(ethylene glycol)-palmitate nanocarrier for curcumin delivery to cancer cells, Acta Biomater. 4 (2008) 1752-1761; DOI: 10.1016/j.actbio.2008.04.021.

13. C. P. Lee and M. N. L. Huang, D-optimal designs for second-order response surface models with qualitative factors, J. Data Sci. 9 (2011) 139-153.

14. M. Wolszczak and J. Miller, Characterization of non-ionic surfactant aggregates by fluorometric techniques, J. Photochem. Photobiol. A: Chem. 147 (2002) 45-54; DOI: 10.1016/S1010-6030(01)00611-6.

15. R. C. Pasquali, M. P. Taurozzi and C. Bregni, Some considerations about the hydrophilic-lipophilic balance system, Int. J. Pharm. 356 (2008) 44-51; DOI: 10.1016/j.ijpharm.2007.12.034. 
J. Varshosaz et al.: Optimization of self-assembling properties of fatty acids grafted to methoxy poly(ethylene glycol) as nanocarriers for etoposide, Acta Pharm. 62 (2012) 31-44.

16. T. Higuchi and A. Connors, Phase-solubility Techniques, in Advances in Analytical Chemistry and Instrumentation (Ed. C. N. Reilly), Wiley, New York 1965, pp. 117-212.

17. F. Bian, L. Jia, W. Yu and M. Liu, Self-assembled micelles of N-phthaloylchitosan-G-polyvinylpyrrolidone for drug delivery, Carbohyd. Polym. 76 (2009) 454-459; DOI: 10.1016/j.carbpol.2008. 11.008.

18. Y. C. Chang and I. M. Chu, Methoxy poly(ethylene glycol)-b-poly(valerolactone) diblock polymeric micelles for enhanced encapsulation and protection of camptothecin, Eur. Polym. J. 44 (2008) 3922-3930; DOI: 10.1016/j.eurpolymj.2008.09.021.

19. M. J. Rosen, Surfactants and Interfacial Phenomena, 3rd ed., Wiley, Hoboken (NJ) 2004, pp. 121; DOI: $10.1002 / 0471670561$.

20. M. Belmares, M. Blanco, W. A. Goddard, R. B. Ross, G. Caldwell, S. H. Chou, J. Pham, P. M. Olofson and C. Thomas, Hildebrand and Hansen solubility parameters from molecular dynamics with applications to electronic nose polymer sensors, J. Comput. Chem. 25 (2004) 1814-1826; DOI: $10.1002 /$ jcc.20098.

\section{$S A \check{Z} E T A K$}

\section{Optimizacija svojstava samoorganiziranja graft kopolimera metoksi poli(etilen glikola) i masnih kiselina pri pripravi nanonosača s uklopljenim etopozidom}

JALEH VARSHOSAZ, FARSHID HASANZADEH i MOJTABA ESLAMDOOST

Cilj je rada bio ispitati svojstva samoorganiziranja micela pripravljenih od graft kopolimera metoksipolietilenglikola (mPEG) i masnih kiselina različite duljine lanca za uklapanje etopozida. Sintetizirana su tri amfifilna kopolimera povezivanjem miristinske, stearinske i behenične kiseline esterskom vezom s mPEG. Veličina i zeta-potencijal micela određeni su metodom dinamičkog raspršivanja svjetlosti. Micele s uklopljenim etopozidom pripravljene su film-metodom pri različitim omjerima lijeka i kopolimera. Oslobađanje lijeka iz micela ispitano je metodom dijalize. Struktura kopolimera potvrđena je ${ }^{1} \mathrm{H}$ NMR i FTIR spektroskopijom. Određivanjem kritičnih micelizacijskih koncentracija utvrđeno je da se s povećanjem duljine hidrofobnog lanca na kopolimerima stvaraju termodinamički stabilnije micele. Među sintetiziranim kopolimerima, micele građene od kopolimera mPEG i behenične kiseline imaju najbolji solubilizacijski kapacitet za etopozid. Učinkovitost uklapanja lijeka u micele ovisi o duljini hidrofobnog dijela u kopolimeru i omjeru lijeka i kopolimera. Najveća učinkovitost uklapanja lijeka utvrđena je za micele mPEG i miristinske kiseline pri omjeru lijeka i kopolimera 1:20. Oko $80 \%$ uklopljenog lijeka oslobađa se iz micela tijekom 5 sati.

Ključne riječi: metoksi poli(etilen glikol), masne kiseline, micele, etopozid

Department of Pharmaceutics, Faculty of Pharmacy and Isfahan Pharmaceutical Sciences Research Center, Isfahan University of Medical Sciences, Isfahan, Iran

Department of Medicinal Chemistry, Faculty of Pharmacy and Isfahan Pharmaceutical Sciences Research Center, Isfahan University of Medical Sciences, Isfahan, Iran 